\title{
AYAT TOLERANSI DALAM AL-QUR'AN PERSPEKTIF TAFSIR AL-KABIR (MAFAATIHUL GHAIB)
}

\author{
Ahmad Zainul Arifin, Khairudin, Moh. Rifa'i \\ IKHC Mojokerto, IAIN Kediri, IKHC Mojokerto \\ arifinzainul89@gmail.com , khairuddinmajid@gmail.com, adam.ravers@gmail.com
}

\begin{abstract}
Abstrak
In the millennial era it is very important in describing the lives of interfaith people on the face of the earth. Various social media certainly become a very important tool for each group to convey ideas quoted based on the teachings of their respective religions. The frequent occurrence of trends in values, morals and ethics causes the relationship between religious people to become increasingly span in the field of trust. Various groups from each religion often complained about their achievements in terms of personality and even on political matters so that such a huge impact is vulnerable to minorities in certain regions. This is where the Qur'an plays a very important role as one of the rejects of Muslim thinking. In addition, the Qur'an also plays an important role for all human beings as social beings without exception. Although al-Qu'an himself has stated that to be one does not have to be the same. Different religions, cultures, nationalities or others is not a limiting thing to build a harmony of living together. It's just that, at the present time many thinkers who stand tall are only for their own sake, don't care about what's around them. For this reason, we are writing a study based on events that often occur on the face of the earth. Inserted with some ideas from several figures and an expert in the interpretation of the Qur'an in order for the writer and the reader to understand more deeply what tolerance is or what harmony is religious life
\end{abstract}

Keywords: Religious tolerance. Tafsir Imam Ar-Razi 


\section{A. PENDAHULUAN}

Berbicara soal agama sangat terkesan perihal toleran maupun intoleran, dalam kurun waktu beberapa tahun terakhir, dunia diguncangkan oleh konflik antar agama, sering kali terjadi kecemasan dan ketidak harmonisan penduduk bumi akibat saling curiga dan tidak percaya antar agama. ${ }^{1}$ Dalam Islam, toleransi merupakan salah satu dari beberapa visi teologi agama, namun untuk mengaplikasikannya perlu pengkajian secara matang dan lebih mendalam, karena pada sejatinya dengan menerapkan sikap toleran niscaya akan tercipta kehidupan yang harmonis dan kerukunan antar umat beragama. ${ }^{2}$ Belakangan ini konsep toleransi dalam agama Islam mendapat sorotan yang sangat tajam, begitulah yang teradi di dunia barat, para kaum Zionis melontarkan perkataannya kepada dunia bahwa Islam adalah agama anti toleran, mereka terus beropini demi merusak citra umat Islam dari dalam. Tentutanya upaya-upaya tersebut akan terus berlanjut dan akan mengancam kesejahteraan Islam jika tidak umat Islam sndiri hanya diam dan tidak mau bergerak untuk memusnahkan apa yang direncanakan para kaum Zionis. ${ }^{3}$

Toleransi dalam Islam memberikan hak mutlak terhadap umat non-Muslim untuk bebas menganut agama apa saja, bukan umat Islam sendiri yang diberikan hak kebebasan tersebut. Konsep toleransi yang diterapkan dalam Islam sendiri untuk menghormati penganut agama lain dan membiarkan mereka untuk melaksanakan ibadahnya dengan tentram dan bebas. Sikap ini seharusnya tidak diterapkan dalam Islam saja, tetapi agama lainpun juga menerapkan sikap yang sedemikian. ${ }^{4}$ Karena pada hakikatnya sikap toleran dalam Islam tidak hanya menjunjung tinggi peradaban dalam Islam sendiri melainkan juga menjunjung peradaban dengan agama lain.

Kurangnya kesadaran beragama menjadi salah satu sebab kekacauan sebuah negara. Di Indonesia sendiri yang dulunya dikenal dengan negara yang sangat menjunjng tinggi keukunan anta beragama kini telah terhipnotis oleh pengaruh dunia barat. Buktinya, sejak masa reformasi orde baru sampai saat ini Indonesia sering mengalami tragedi yang memicu ketegangan umat beragama, seperti

\footnotetext{
${ }^{1}$ Muhammad Yasir. Makna Toleransi dalam al-Qur'an, Jurnal Ushuluddin. Vol. XXII No. 2, juli 2014 http://ejournal.uin-suska.ac.id/index.php/ushuludin/article/view/734

2 Ibid. Hal. 170

3 Ibid. Hal. 170-171

4 Alpizar, Islam, Toleransi, dan Kebebasan beragama. TOLERANSI: Media Komunikasi Umat Bergama, Vol.7, No.2 Juli-Desember 2015 http://ejournal.uin-suska.ac.id/index.php/ toleransi/article/view/1426
} 
terjadinya teror pengeboman di berbagai tempat, tidak peduli itu di Masjid, Gereja, Hotel, ataupun tempat lainnya. Dan hal tersebut diduga sebagai kelanjutan dari tragdi yang menimpa gedung Pentagon dan gedung World Trade Cebter di Amerika pada 11 September 2001 silam. Pasca inilah banyak sekali gerakan-gerakan radikal dalam Islam yang muncul akibat aksi teror yang kerap terjadi yang kemungkinan besar merupakan lanjutan dari tragedi 11 September $2001 .^{5}$

Kita meyakini bahwa kemakmuran sebuah negara bertumpu terhadap sikap toleran penduduknya. Keanekaragaman agama dan budaya menjadi tali penyambung sebuah bangsa harus tetap dijaga bersama. Dan kita lihat sendiri kondisi bangsa kita, bangsa Indonesia yang terdiri dari berbagai budaya dan agama di dalamnya sangat banyak ditemukan toleransi yang ditunjukkan oleh berbagai kalangan yang berbeda. Hanya saja, sering kita temui ulasan di media masa yang menunjukkan wajah-wajah intoleran yang berksan bahwa bangsa ini sudah miskin dengan kerukunan hidup. ${ }^{6}$

Toleransi bukanlah hal yang asing bagi bangsa Indonesia. Terjadinya konflik di berbagai belahan dunia akan segera merambat ke nusantara. Hal tersebut disebabkan kondisi bangsa Indonesia yang begitu rentan dengan suasana konflik. ${ }^{7}$

\section{B. DEFINISI TOLERANSI}

Rasulullah SAW bersabda:

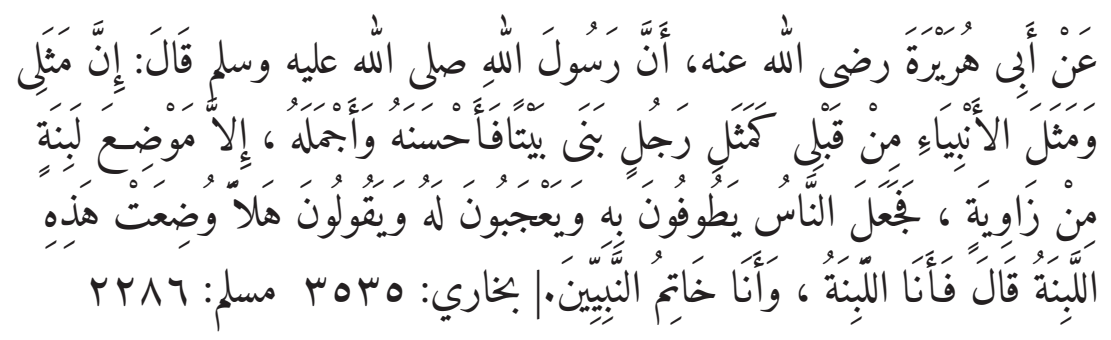

5 Muhammad Ridha Dinata. “Konsep Toleransi Beragama Dalam Tafsir Al-Qur'an Tematik Karya Departemen Agama Republik Indonesia”.ESENSIA: Jurnal Ilmu-Ilmu Ushuluddin Vol. XIII No. 1 Januari 2012 85-108 http://ejournal.uin-suka.ac.id/ushuluddin/esensia/ article/view/723/665

6 Ahsanul Khalikin dan Fathuri. 2016. Toleransi Beragama di Daerah Rawan Konflik. Jakarta, Puslitbang Kehidupan Keagamaan. Hal. vii

7 Ibid. Hal. xi 
Dari Abu Hurairah RA, Rasulullah SAW bersabda: Perumpamaankuku dan perumpamaan para nabi terdabulu, yaitu seperti seseorang yang membangun rumah lalu menyempurnakannya dan memperindahnya kecuali sebuah batu di bagian pojok rumah. Kemudian orang-orangyangmengelilingi dan mengagumi rumah tersebut, mereka bertanya, kenapa batu ini tidak diletakkan? Rasulullah SAW menjawab, "saya adalab batunya dan saya adalah penutup para Nabi.” (HR. Bukhari, no. 3535 dan Muslim, no. 2286). ${ }^{8}$

Hadits di atas merupakan salah satu rujukan penting dalam membangun toleransi dalam konteks antar umat beragama. Yang menarik dari kandungan hadits tersebut ialah cara Nabi dalam menyikapi agama-agama sebelum Islam, khususnya agama Yahudi dan Kristen, yang menyatakan bahwa agama ibarat sebuah rumah. Rumah yang sudah dibangun bahkan terbentang dengan megah. Ajaran yang dibawa oleh Nabi bukan untuk menghancurkan atau merusak rumah tersebut, melainkan ajaran yang dibawa Nabi bertujuan untuk memperindah dan menyempurnakan agama-agama yang sebelumnya. Terutama agama Yahudi dan Kristen yang diibaratkan rumah yang begitu megah. Sabda Nabi tersebut membuktikan bahwa toleransi dalam Islam memiliki akar-akar teologis yang sangat kuat. Seperti, dilihat dari dua pilar dari enam pilar agama yang berbunyi "Iman kepada kitab dan utusan Allah". Kedua pilar merupakan dasar toleran dan keharmonisan hidup. Oleh karena itu toleransi dalam Islam bukanlah hal yang baru, melainkan Nabi sendiri telah mempraktekkannya dengan cara mengakui eksistensi agama terdahulu dan menyempurnakan ajarannya. ${ }^{9}$

Rasulullah SAW saat melakukan dakwah selalu memberikan contoh toleransi terhadap kaum non muslim, seperti halnya beliau saat berdakwah di Madinah, beliau memberikan kebebasan terhadap masing-masing individu untuk beraktivitas keagamaan yang dianutnya, baik itu dari kalangan Islam, Yahudi, Nasrani maupun kalangan yang lain. Diceritakan bahwa suatu ketika Nabi didatangi delegasi Kristen Najra, beliau mempersilahkan mereka di Masjid. Saat itu beliau sedang melaksanakan sholat ashar, lalu para delegasi Kristen tersebut meminta izin kepada Nabi untuk melakukan kebaikan di

8 HR. Bukhari, no. 3535 dan Muslim, no. 2286.

9 Misrawi, Zuhairi. Al-Qur'an Kitab Toleransi, Tafsi Tematik Rahmatan Lil 'Alamin. Jakarta: Pustaka Oasis. 2010 Hal. 196 
masjid dan beliaupun membiarkan mereka mengerjakan kebaktiannya. ${ }^{10}$

Pada dasarnya, artian "toleransi" secara etimologi diambil dari dua bahasa yang berbeda. Yang pertama bahasa Inggris tolerance yang bermakna kebebasan, dalam artian memberikan kebebasan terhadap sesama individu maupun sesama kelompok. Kemudian yang kedua diambil bahasa Latin tolerantia yang bermakna sabar dan sikap lemah-lembut, kalimat tersebut menjadi slogan di bumi Eropa terutama pada masa Revolusi negara Perancis. Dan dalam bahasa Arab toleransi lebih dikenal dengan kata tasamuh yang secara umum bermakna akhlak atau sikap yang terpuji, yang mana pada dasarnya sikap ataupun akhlak yang baik tersebut timbul dari hati yang bersih, sehingga setiap individu maupun kelompok yang menanamkan sikap toleran juga bisa dikatakan orang-orang yang terpuji, tergantung cara bagaimana mereka menyikapi orang lain yang searah dengan pemahamannya maupun yang bertolak dengan pemahamannya. Namun, dalam al-Qur'an sendiri toleransi bermakna hanya sebatas menghormati dan menghargai tehadap penganut kepercayaan lain saja. Karena prinsip yang paling mendasar perihal toleransi dalam Islam menyatakan bahwa agama Islam sendirilah yang paling benar. Namun Islam sendiri tidak memaksa umat non muslim untuk pindah agama ke dalam Islam. ${ }^{11}$

Andi Nirwana menyebutkan dalam tulisannya juga tentang toleransi sesungguhnya merupakan salah satu inti ajaran Islam.Toleransi sejajar dengan ajaran fundamental yang lain, seperti kasih-sayang (rahmah), kebijaksanaan (hikmah), kemaslahatan universal (al-mashlahah 'alamiah), dan keadilan (al-'adl). Beberapa prinsip ajaran Islam ini merupakan sesuatu yang pasti, ia tidak bisa dianulir atau dibantah dengan nalar apa pun. Ajaran-ajaran tersebut bersifat universal dengan melintasi rentang waktu dan dimensi tempat (shlih likulli zaman wa makan). Pendeknya, prinsip-prinsip ajaran ini bersifat transhistoris, transideologis, bahkan trans-keyakinan-agama. ${ }^{12}$

Toleransi mengandung prinsip mewujudkan kerukunan hidup. Dapat dilihat dari beberapa konteks : Pertama, persaudaraan yang bersifat manusiawi dan universal. Seluruh umat manusia mengaku bahwa dirinya adalah berasal

${ }^{10}$ Bagus Purnomo. Toleransi Religis: Antara Plralisme dan Pluralitas. Lajnah Pentashihan Mushaf Al-Qur'an. Jakarta: Vol. 6, No. 1, 2013: 83-103. Hal. 88

${ }^{11}$ Muhammad Ridha Pranata. Konsep toleransi beragama dalam tafsir al-qur'an tematik karya tim departemen agama republik Indonesia. ESENSIA Vol. XIII No. 1 Januari 2012. Baca juga Muhammad Yasir, Makna Toleransi Dalam Al-Qur'an. Jurnal Ushuluddin Vol. Xxii No. 2, Juli 2014

${ }^{12}$ Andi Nirwana, “Wawasan Al- Qur'an Tentang Toleransi." Jurnal Tafsere 1, no. 1 (2013). http://journal.uin-alauddin.ac.id/index.php/tafsere/article/view/7451 
dari keturunan Adam dan Hawa yang diyakini oleh umat Islam bahwa Adam adalah nabi dan rasul yang pertama dan Muhammad adlah nabi yang terakhir. Kedua, Islam mengajarkan bahwa seluruh umat manusia dilahirkan dalam keadaan fitrah (suci). Sejak dilahirkan manusia sudah membawa fitrahnya masing-masing. Manusia dibekali akal untuk mampu mencari, memahami dan mempertimbangkan suatu kebenaran, yang pada akhirnya akan mengarahkan dirinya terhadap sang penciptanya dan mengakuinya sebagai Tuhannya. Dalam Islam, kecenderungan seperti inilah yang disebut sebagai hanif yang diidentikkan dengan ajaran Nabi Ibrahim dalam perjalanannya mencari kebenaran dan akhirnya menemukan tuhannya. Nabi Ibrahim dikenal sebagai panutan bagi agama-agama samawi. Nabi Muhammad sendiri pernah menyatakan bahwa "Islam identik dengan Hanifiyah."13. kata "hanif" mempunyai arti sebagai orang-"orang yang berserah diri (karena condong dalam kebaikan)" ${ }^{14}$ sebagaimana yang dilakukan Nabi Ibrahim dalam mencari kebenaran. Maka, al-Qur'an disitu lebih mempertegas lagi bahwa Nabi Ibrahim bukanlah orang yang beragama Yahudi maupun Nasrani melainkan orang yang berpasrah diri kepada Allah dan bukan orang yang musyrik. Diperkuat lagi oleh sabda Nabi, bahwa "Agama yang paling dicintai Allah ialah berserah diri dan toleran"15

Sikap toleransi mengakui adanya berbagai perbedaan, baik dari sisi keagaman, suku bangsa, budaya, adat-istiadat dan sebagainya. Semua sudah menjadi fitrah dari Tuhan dan kita sebagai makhluk Tuhan wajib untuk menerimanya. Landasan pemikiran ini sudah tertera dalam al-Qur'an surat al-Hujurat ayat 13:

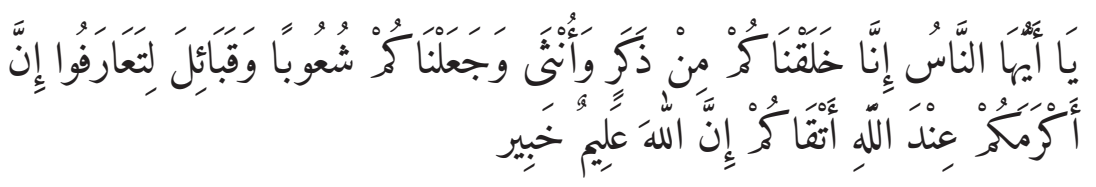

"hai manusia, sesungguhnya kami menciptakan kamu dari seorang laki-laki

${ }^{13}$ Hanifiyah sudah dikenal dalam tradisi Arabia pra Islam, mereka menolak setiap pengasosiasian tuhan-tuhan palsu dengan Tuhan yang sebenarnya, karena perbuatan semacam ini adalah syirik. Oleh karena itulah, mereka menolak untuk berpartisipasi dalam ritual-ritual pagan dan berusaha mempertahankan kesucian teologi mereka. Lihat Azyumardi Azra dalam Weinata Sairin, Kerukunan Umat Beragama, h. 93. Baca juga dalam Analisis teologi kerukunan beragama dalam Islam Volume XIII, Nomor 2, Desemberi 2013. oleh: adeng muchtar Ghazali

${ }^{14}$ Adnan Tharsyah, Manusia yang Dicintai dan Dibenci Allah: Kunci-kunci Menjadi Kekasih Allah (Bandung: Mizania, 2008), hal. 25.

15 Tharsyah, Manusia, hal. 25. 
dan perempuan dan menadikan kamu berbangsa-bangsa dan bersuku-suku supaya kamu saling kenal-mengenal. Sesngguhnya orang yang paling mulia di antara kamu di sisi Allah ialah orang yang paling bertaqwa di antara kamu. Sesngghnhya Allah maha mengetahui lagi maha mengenal"

Seluruh umat manusia tidak bisa berpaling dari ayat di atas, baik mereka yang muslim maupun non Muslim. Sudah menjadi takdir tuhan agar manusia dapat menerima perbedaan-perbedaan yang ada. Dalam teologi Islam toleransi antar agama merupakan risalah yang amat penting, karena itu tuhan senantiasa mengingatkan hambanya supaya tetap dalam kebenaran meskipun sering kali menghadapi perbedaan-perbedaan dalam menjalani hidup. ${ }^{16}$

Toleransi dalam beragama bukan berarti umat manusia bebas menganut agama secara gonta-ganti. Karena beragama bukanlah sebuah kebutuhan hidup melainkan kepercayaan dan pengakuan diri kita terhadap adanya tuhan yang kita sembah. Jika kita bebas gonta-ganti agama maka tidak ada bedanya kita disebut mempermainkan Tuhan, dan hal tersebut tentnya akan menjadi pelecehan terhadap agama yang dianutnya secara gonta-ganti.

Sikap toleransi merupakan salah satu acuan masyarakat dalam membangun kesejahteraan sosial maupun kesejahteraan agama, yang menjadi tali pengikat agar tidak terjadi kesalah pahaman di antara mereka. Apa jadinya jika sesama manusia tidak menanamkan sikap toleran, tidak saling mempercayai, dan tidak saling menghargai. Tentunya hal tersebut akan memicu pergejolakan dan dapat mengakibatkan konflik antar satu pihak dengan pihak yang lain. Islam menawarkan toleransi yang sangat rasional dan praktis, kecuali dalam hal aqidah dan beribadah Islam tidak mengenal kata tawar menawar. Ini menandakan bahwa umat Islam sangat berbeda dengan umat agama lain dari tata cara ibadah dan apa yang disembahnya. Namun, Islam tetap menjaga sikap toleran dengan melarang menghina dan mencaci maki Tuhan agama lain. ${ }^{17}$

Akan tetapi jika kita memandang ke zaman modern seperti sekarang sangat tragis apabila membicarakan hal yang berkenaan dengan kerukunan antar umat beragama. Banyak sekali ditemukan ketidak toleran sesama individu maupun kelompok, baik di dalam negri maupun di luar negri. Seperti contoh kasus pengusiran kaum Syiah yang terjadi di Sampang tepatnya di Desa Karanggayam Kecamatan Omben, dan kasus pembantain kaum Muslim di Rohingya

\footnotetext{
${ }^{16}$ Said Husin Aqil Al Munawar, al-Qur'an Membangun Tradisi Kesalehan Hakik. hlm. 108.

${ }^{17}$ Muhammad yasir. Makna Toleransi dalam al-Qur'an, Jurnal Ushuluddin. Vol. XXII No. 2, juli 2014. Hal. 170
} 
Myanmar, belum lagi peristiwa yang menimpa negri Palestina dimana para kaum Zionis sangat antusias dalam mengobrak-abrik negri Palestina demi perluasan wilayah yang berkedok keagamaan. Dan masih banyak lagi di luar sana mengenai kasus seperti tersebut. Kurangnya kesadaran diri dan pengetahuan bisa menjadi tolak ukur sebuah perpecahan sesama agama maupun antar agama. Maka dari itu diperlukan sebuah cara untuk menghindari peristiwa seperti di atas yakni dengan cara berdialog antar agama yang mana nantinya akan ditemukan titik pertentangan yang menjadikan alasan kenapa hal tersebut terjadi. Nah, dan setelah ditemukan titik pertentangannya maka antara satu pihak dengan pihak yang lain harus menerapkan sikap kedewasaanya, harus tetap saling menghormati dan menjaga privasi antar sesama sesuai perjanjian yang telah ditentukan. ${ }^{18}$

Para Ilmuan berbeda dalam mendefinisikan toleransi. Mernurut Micheal Wazler 1997, toleransi merupakan keniscayaan dalam kehidupan masyarakat individu maupun publik karena usaha dalam upaya membangun kehidupan yang damai. Heiler menyatakan bahwa sikap toleransi harus diwjujudkan untuk menghadapi sikap pluralitas agama atas dasar kesadaran ilmiah dengan cara membangun hubungan yang bersahabat antar agama lain. Djohan Efendi dalam bukunya menyederhanakan arti toleransi, menurutnya toleransi adalah sebuah sikap dalam menghargai kemajemukan. Sullivan, Pierson dan Marcus dalam kutipan Saiful Majjani, menjelaskan toleransi didefinisikan sebagai a willingness to put with those things one rejects or opposes, yakni "kesediaan untuk menghargai, menerima atau menghormati segala sesuatu yang ditolak atau ditentang oleh seseorang” (Saiful Mujani, 2007 162). Benyamin Intan dalam karya tulisnya "public Religion and the Pancasila-Based State of Indonesia" mengutip dari pendapat David Little mendifinisikan toleransi dalam dua bagian: pertama dalam bentuk deifinisi yang lemah, toleransi adalah jawaban sebuah kepercayaan, atribut atau praktik yang pada asalnya tidak diterima atau dianggap menyimpang, dengan ketidak setujuan, tetapi tanpa adanya paksaan. Kedua, dalam bentuk definisi yang akurat, toleransi diartikan sebagai jawaban sebuah kepercayaan, atribut atau praktik yang pada asalnya tidak diterima atau dianggap menyimpang, dengan ketidak setujuan yang disublimasi, tetapi tanpa adanya paksaan. Dengan demikian, toleransi tidak hanya berangkat dari kesadaran diri saja, tetapi juga semangat, perjuangan dan gairah demi membangun hidup yang lebiih baik. Dalam Deklarasi Prinsip-Prinsip Toleransi (UNESCO) dinyatakan bahwa toleransi adalah sebuah rasa hormat, penghargaan dan pene-

${ }^{18}$ Ibid. Hal 170 
rimaan terhadap keragaman budaya dunia, berbagai bentuk tata cara menjadi manusia dan mengekspresikannya. Toleransi adalah bentuk kerukunan dalam perbedaan. ${ }^{19}$

Dalam konteks di atas dapat di tarik pemahaman bahwa toleransi adalah sebuah bentuk kesadaran individu maupun kelompok yang berbeda agama dalam sebuah kehidupan berdampingan atau kerjasama antar agama. Sebab pada hakikatnya untuk menjalin hubungan ataupun membangun sebuah kehidupan yang tentram tidak lepas dari prasyarat yang mana nantinya akan dijadikan landasan dalam hubungan maupun dalam kehidupan tersebut, dan prasyarat sendiri itu adalah sikap toleransi sesama agama maupun antar agama lain. Pastinya sikap tersebut akan mewujudkan hubungan dan kehidupan yang baik dalam ruang lingkup yang beraneka ragam agama atau kepercayaan. Dan yang dimaksud dengan toleransi dalam agama di sini ialah hal-hal yang bersifat mencerminkan diri terhadap agam lain, baik itu berupa perilaku, pemikiran maupun kepercayaan. ${ }^{20}$

\section{BIOGRAFI IMAM AR-RAZI}

Nama lengkapnya Muhammmad bin Husain bin Hasan bin Ali At-Taimi Al-Bakri At-Thabari lahir pada tahun $544 \mathrm{H}$ di kota Al-Ray, wafat pada tahun $606 \mathrm{H}$ di kota Harrah., beliau bermaszhab Syafi'i. Beliau dijuluki Syaikhul Islam dan mendapati banyak gelar beberapa di antaranya Ibnu Al-Khatib, Abil Fadl, Abî Abdillah, Abil Ma’ali, Al-Ray. ${ }^{21}$ Capaian gelar-gelar tersebut sebab beliau adalah seseorang yang sangat luas ilmu pengetahuannya. Dalam bidang tafsir beliau sangat dikenal dengan julukan Fakhru ar-Razi atau Fakhruddin ar-Razi. Dalam salah satu karyanya yang terkenal Mafaatihul Ghaaib beliau menggambarkan berbagai macam ilmu yang bersifat disiplin (disiplin ilmu) seprti ilmu ushul fiqh, ilmu fiqh, ilmu nahwu, ilmu balaghah, astronomi dan ilmu-ilmu yang lainnya yang beliau tulis. Dan menurut Abu Hayyan Imam Ar-Razi mengumpulkan berbagai macam hal dalam kitabnya mafaatihul Ghaib, sehingga kitabnya tersebut sering dijadikan rujukan oleh berbagai peneliti. Setelah ayahnya wafat Imam Fakhruddin Ar-Razi juga pernah mempelajari filsafat islam seperti filsafa Ibnu Sina dan Al-Farabi bahkan beliau juga mempelajari filsafat barat seperti

\footnotetext{
${ }^{19}$ Ahsanul Khalikin dan Fathuri. 2016. Toleransi Beragama di Daerah Rawan Konflik. Jakarta, Puslitbang Kehidupan Keagamaan. Hal. 12

${ }^{20}$ Ibid. Hal. 12

${ }^{21}$ Ar-Razi, Mafaatihul ghaib. Beirut: Libanon, Madlr Azhar, 1997 jil. II. hal 3
} 
filsafat Aristoteles, Plato. Dalam keilmuan kalam dan fiqihnya beliau dinyatakan hampir setingkat dengnan imam Syafi'i bahkan melampauinya, karena beliau selalu berhasil memecahkan permasalahan yang ada dalam kiab-kitab fiqih maupun kalam. Sosok yang dikenal dengan lemah lembut dan kesopanannya ini ternyata menguasai dua bahasa yaitu bahasa Arab dan bahasa Persia. Di kehidupannya yang mulai menua beliau hidup sebagai seorang sufi, karena pada sebelumnya beliau merasa sangat tidak tenang dikarenakan faktor keilmuan kalam dan filsafatnya yang sangat mendalam, beliau merasa tenggelam dalam keilmuannya itu sendiri. Dan setelah beliau fokus untuk menekuni ilmu syariat, dan alhasil beliau mencetuskan sebuah pendapat bahwa "akidah yang benar terdapat dalam kesufian dan ilmu syari'at".22

Memang banyak sekali ulama yang memberi pujian terhadap imam Ar-Razi, akan tetapi ada juga ulama yang tidak sependapat bahkan mengecam dan mencela beliau, antara lain ulama tersebut Al-Hafiz Az-Zahabi, menurut beliau Imam Ar-Razi adalah seseorangyang memiliki kecerdasan di atas rata-rata kecerdasan manusia pada umumnya, akan tetapi pemikirannya dapat merubah permasalahan dalam agama yang sifatnya substansial. Selanjutnya Imam Al-Hafiz mengklaim bahwa salah satu kitab karya Imam Ar-Razi yang berjudul "As sirrul Maktum Fî̀ Mukhatabatin Nujüm" (rahasia yang tersembunyi dalam perbincangan bintang-bintang) adalah kitab yang terdapat sihir di dalamnya. Selain pernyataan tersebut ada lagi kritik yang lebih parah dari ulama lain yaitu As-syadafi. As-Syadafi mengatakan bahwa Imam Fakhruddin Ar-Razi lebih tunduk terhadap pemikian Aristoteles dan Ibnu Sina dan telah menyimpang dari ajaran ablus sunnah wa al-jamaah. Ditambah lagi dengan kritik sebagian ulama yang menyatakan bahwa Imam Ar-Razi adalah sosok yang miskin yang sama skali tidak ada manfaat dari apa yang diperolehnya. Namun tidaklah semua ulama berfikir dan berpendapa bahwasannya Imam Ar-Razi telah menyimpang dari ajaran ablus sunnah wa al-jamaah sebagaimana yang telah dijelaskan di atas, ada sebagian besar ulama yang sependapat bahkan mendukung dengan pemahaman Imam Ar-Razi. Salah satunya Imam Muhyiddin Arabi yang merupakan seorang tokoh besar dari kalangan sufi yang hidup semasa dengan Imam Ar-Razi, ditambah lagi dengan dukungan 106 ulama yang menyatakan bahwa pemikiran Imam Ar-Razi memberikan dampak perkembangan terhadap dunia islam. Jadi, wajar saja jika ada tokoh ulama lain yang merasa iri hati terhadapnya

${ }^{22}$ Muhammad Ali Ayāzi, Al-Mufasirūn Hayātuhum wa Manhājuhum, Cet. 1, Taheran: Wizanah Al-Tsiqafah wa Al-Insyaq Al-Islam, 2002 M, h. 651. 
karena beliau sendiri sangat terpandang di mata umat. ${ }^{23}$

Buah dari kecerdasan beliau tertuang di dalam beberapa kitabnya, antara lain: Ikhțisaru Dalāilil I'jāz, Asrārut Tanzīl Wa Anwārut Tàwīl, I'tiqādatu Firāqil Muslimin Wal Musyrikin, Al-Bayān Wal Burhān Fîr Raddi 'Ala Abliz Zaygi Waț Tugyān, Tafsìr Asmäul Husna, Tafsìr Al-Qurān Al-Kabì (Mafätîhul Ghaib), At-Tanbih 'Ala Bádlil Asmail Muwadda'ati Fî̀ Badli Sūwāril Qur'ān, Aț-Ṭariqatu Fîl Jidali, Faḍailuș Șahābāt, Fî Ibțalil Qiyās, Jawāmìul Bayān Fî̀ Syarhi Asmāillabil Husna Waș Șifät, Al-MahșulFì 'Ilmi Ușulil Fiqhi, Manāqibul Imām Aș-Safíl, Nihāyatul Ijāzi Fî Dirayātil I’jaz. Karya-kaya tersebut membuktikan bahwa Imam Ar-Razi sangat menjunjung tinggi berbagai macam ilmu pengetahuan tidak terbatas pada penyampian dan komnikasi saja. ${ }^{24}$

Mengenai kitab tafsir mafaatihul ghaib sendiri disusun oleh Imam Ar-Razi atas 32 jilid. Dalam peunlisan kitab tafsir ini Imam Ar-Razi menggunakan pendekatan akal (tafsir bi ar-ráyi). Dan beliau tetap merujuk terhadap pendapat-pendapat yang sohih, beliau tidak pernah egois dan hanya terpatok dengan pengetahuannya saja meskipun beliau sendiri menguasai berbagai macam disiplin ilmu.

Adapun tujuan Imam Ar-Razi dalam penulisan kitab ini antara lain: Menjaga kandungan Al-Qur'an dari berbagai kecenderungan rasional, membuktikan eksistensi Allah swt melalui dua hal. Pertama, dengan bukti "terlihat" (dalam bentukwujud kebendaan dan kehidupan). Kedua, dengan bukti "terbaca” (dalam bentuk Al-Qur’ān). Poni berikutnya, Imam Ar-Rāzî ingin menegaskan sesungguhnya studi balagah dan filsafat bisa dijadikan sebagai materi tafsîr, serta digunakan untuk menakwil ayat-ayat Al-Qur’ān, selama berdasarkan kepada kaidah-kaidah yang jelas, yaitu kaidah Ablu Sunnah Wal Jamaiah.

Muhammad Husain Az-Zahabi mengatakan bahwa dalam penulisan kitabnya Imam Ar-Razi fokus terhadap empat metode: Fokus terhadap penjelasan munasabah antar satu ayat dengan ayat yang lain atau antar satu surah dengan surah yang lain. Menggunakan argumen filsafat dan ilmu pasti. Mengadopsi pendapat mu'tazilah meskipun ada beberapa pendapat yang di tajrih. Memperluas penafsiran dengan kajian Ilmu Fiqih, Ușul, Naḥwu dan Balagah di dalam tafsîr.

\footnotetext{
${ }^{23}$ Ibid. Hal. 653

${ }^{24}$ Ibid. Hal. 652
} 


\section{PENAFSIRAN IMAM AR-RAZI TERHADAP AYAT-AYAT TOLERANSI DALAM AL-QUR'AN}

Dalam surah al-kafirun ayat 1-6:

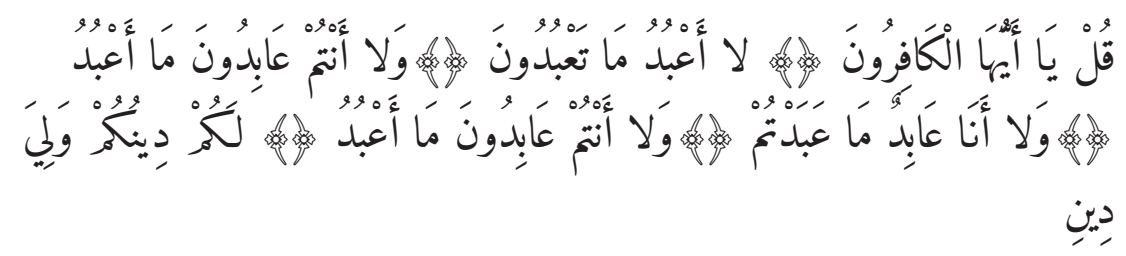

"katakanlah (Muhammad), 'wahai orang-orang kafir! Aku tidak akan menyembah apa yang kamu sembah, dan kamu bukan penyembah apa yang aku sembah, dan aku bukan penyembah apa yang kamu sembah, dan kamu tidak akan pernah menjadi penyembah apa yang aku sembah, untukmu agamamu dan untukku agamaku"' (QS. Al-Kafirun : 1-6) ${ }^{25}$

Sebab turunnya ayat. At-Thabrani dan Ibnu Hatim meriwayatkan dari Ibnu Abbas, dia menuturkan: orang orang Qurays telah berusaha mempengaruhi Rasulullah SAW dengan menawarkan harta kekayaan agar beliau menjadi orang yang paling kaya di kota Mekah. Mereka juga menawarkan kepada beliau untuk menikahi wanita mana saja yang beliau kehendaki. Upaya tersebut mereka sampaikan kepada beliau seraya berkata, "inilah yang kami sediakan bagimu wahai Muhammad, dengan syarat engkau jangan memakimaki tuhan-tuhan kami selama setahun". ${ }^{26}$ Rasulullah SAW menjawab; "aku akan menunggu wahyu dari Rabbku”, kemudian turunlah surah Al-Kafirun: 1-6. Dan turun pula ayat

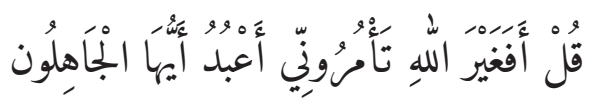

katakanlah (Muhammad), "apakah kamu menyurub aku menyembah selain Allah, wahai orang-orangyang bodoh?" (QS. Az-Zumar : 64) ${ }^{27}$

Diriwayatkan oleh Abdurrazaq bahwa Wahab menuturkan: suatu hari orang-orang kafir Qurays berkata kepada Rasulullah SAW, "sekiranya engkau

\footnotetext{
${ }^{25}$ QS. Al-Kafirun : 1-6

${ }^{26}$ Imam Suyuthi. Asbaabun Nuzul. Solo; Insan kamil. 2016 cet. I. Hal. 707. Baca juga sanadnya la' ba'sa bih, yang diriwayatkan oleh At-Thabrani dalam Al-Ausath (nomor 751)

${ }^{27}$ QS. Az-Zumar : 64
} 
tidak keberatan mengikuti kami (menyembah berhala) selama setahun, maka kami akan mengikuti agamamu selama setahun pula," maka Allah menurunkan firmannya dalam surah Al-Kafirun ayat 1-6. ${ }^{28} \mathrm{Ibnul}$ Mundzir juga meriwayatkan kisah yang sama melalui jalur Ibnu Juraij.

Ibnu Abi Hatim meriwayatkan dari Sa'id bin Mina, dia menuturkan bahwa suatu hari Al-Walid bin Al-Mughirah, Al-Ash bin Wa'il, Al-Aswad Al-Muthalib, dan Umayyah bin Khalaf menemui Rasulullah SAW. Mereka berkata; "wahai Muhammad, sembahlah apa yang kami sembah dan kamipun akan menyembah apa yang engkau sembah. Setelah itu kami akan mengikut sertakan kamu dalam urusan kami." Maka Allah menurunkan firmannya dalam surah Al-Kafirun ayat 1-629

Dalam kitabnya, Imam Ar-Razi menyatakan bahwa ayat tersebut mengandung arti bagi kalian adalab kekafiran yang kalian anut, dan bagiku berpegang dengan ajaran taubid dan keikhlasan akan hal tersebut, penafsiran tersebut hampir sama denga penafsiran Imam Ibnu Katsir. Maksudnya, tidak ada unsur pemaksaan dalam menganut agama apapun, biarlah mereka (orangorang kafir) tetap menganut agamanya sendiri, begitupun juga dengan nabi akan tetap berpegang teguh terhadap agama islam. ${ }^{30}$

Dalam menafsirkan ayat tersebut, Imam Ar-Razi menggunakan metode bi ar-ra'yi dengan melalui tiga tahapan. Yakni, analisa langsung, analisa khusus (memakai term al-masalah) dan analisa lapangan (metode dialog). Yang pertama, dengan metode analisa langsung, Imam Ar-Razi memaparkan seluruh kandungan surat beserta faedah-faedahnya yang dikutip dari setiap huruf-hurufnya, seperi lafadz "qul" yang menurutnya mempunyai 43 faedah.. yang kedua, Imam Ar-Razi mengkaji ayat tersebut secara khusus, dengan menggunakan kata kunci al-masalah mengenai: bahasa, seperti kandungan lafadz "yaa ayyuha", gramatika (nahwu), seperti tidak adanya tikrar dalam ayat ke-dua sampai ke-lima, dan faidah nasr yang terdapat pada ayat terakhir. Dan yang ketiga, Imam Ar-Razi melakukan analisa lapangan, dalam hal ini Imam Ar-Razi memantapkan pembahasan dalam bentuk pertanyaan dengan menggunakan kata as-su'al yang kemudian desertakan dengan jawabannya. Hal ini terkait dengan pendapat Usul seperti dalam penggunaan kata kafir dalam surat ini dengan kata jabl dalam surat At-Tahrim yang memiliki keserupaan dari segi

\footnotetext{
${ }^{28}$ Imam Suyuthi. Asbaabun Nuzul. Solo; Insan kamil. 2016 cet. I. Hal. 707. Baca juga sanadnya la' ba'sa bih, yang diriwayatkan oleh At-Thabrani dalam Al-Ausath (nomor 708)

${ }^{29}$ Ibid. Hal 708
} 
asbabunbuzulnya dan menggunakan tikrar pada ayat ketiga dan kelima.

Mengenai surat ini ini Imam Ar-Razi menggunakan riwayat seperti terlihat dalam menentukan sebab turunnya. Pandangan Ar-Razi mengenai ayat terakhir bahwa Nabi SAW tidak memberikan ijin kepada umatnya untuk melakukan kekufuran, karena hakikatnya Nabi diutus untuk menunjukkan umatnya ke dalam kebaikan dan mencegahnya dari kerusakan.

Selanjutnya Imam Ar-Razi menjelaskan kandungan dari beberapa lafad yang terdapat pada ayat terakhir. Seperti, kata ad-din yang diartikan sebagai perhitungan (hisab), sebagai hukuman, sebagai seruan, dan yang terakhir sebagai adat atau kebiasaan. ${ }^{31}$

Dalam surah al-kahfi : 29

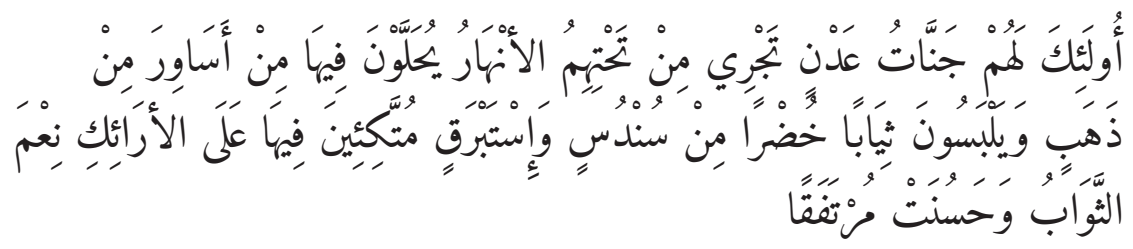

Dan katakanlah, kebenaran itu datangnya dari tuhan, maka barangsiapa yang ingin beriman hendaklah dia beriman, dan barangsiapa yang ingin kafir hendaklah ia kafir. Sesunguhnya kami telah sediakan neraka bagi orang-orang dzalim, yang gejolaknya mengepung mereka. Dan jika mereka memita minum, niscaya mereka akan diberi minum dengan air seperti air besi yang mendidih, yang menghangskan muka. Itulah minuman yang paling buruk dan tempat istirahat yang paling jelek ${ }^{32}$

Terdapat beberapa kandugan makna yang peting dari ayat di atas. Yang pertama, bahwa tuhan adalah sumber kebenaran. Terdapat beberapa poin dalam makna yang digarisi oleh Imam Ar-Razi. Pada masa Nabi Muhammad orang-orang kaya sanngat berkuasa dan mereka hendak menyingkirkan orang orang miskin. Namun melalui ayat di atas tuhan menyampaikan kepada nabi bahwasannya nabi hendak menegaskan dan tidak betekuk lutut tehadap mereka karena pada hakikatnya kebenaran tidak berseumber dari orang-orang kaya melainkan dari tuhan semata. Dalam konteks ini imam Ar-Razi berpendapat bahwa ayat tersebut menegandung arti supaya nabi tetap bersabar akan

\footnotetext{
${ }^{31}$ Ar-Razi. Mafaatihul Ghaib. Jil. XXXI (Beirut: Libanon, Madlr Azhar, 1997), hlm. 136. Baca juga skripsi, studi atas penafsiran ar-Razi dalam kitab Mafaatihul Ghaib. Tafsir Hadits. Fak. Ushuluddin UIN Sunan Kalijaga. 2005|Yogyakarta

${ }^{32}$ Al-baqoroh ayat 62
} 
kefakiran ummatnya, dan hendak melindungi dan menjaga mereka yang fakir dari kedholiman para penguasa yang tamak.

Al-baqoroh ayat 62 .

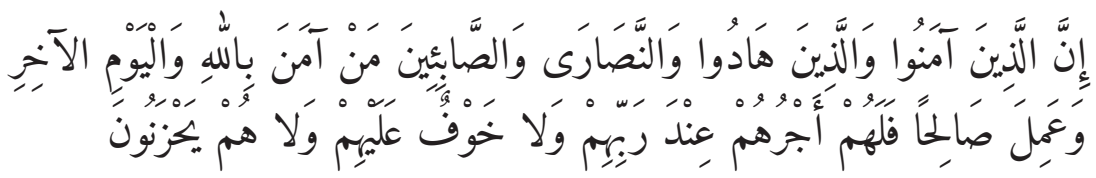

"Sesungguhnya orang-orang yang beriman dan mereka yang beragama yahudi, kristen dan kaum sabian, baang siapa beriman kepada allah, hari akhir dan beramal soleh maka mereka mendapatkan pahala disisi than mereka, mereka tidak akan takut dan tidak pula bersedih."

Mengenai asbabun nuzul ayat tersebut, Ibn Hatim dan Al-Adni meriwayatkan dalam musnadnya, dari jalur Ibnu Abu Nujaih, dari Mujahid dia menuturkan : Salman mengisahkan, ketika aku bertanya kepada Rasulullah SAW. tentag agama yang pernah ku anut sebelum ini, sekaligus ku ceritakan kepada beliau tata cara mereka shalat dan beribadah. Maka Allah menurunkan ayat ini. ${ }^{33}$

Al-Wahidi meriwayatkan dari jalur Abdllah bin Katsir, dari Mujahid dia menuturkan: ketika Salman bercerita kepada Rasulullah SAW tentang rekanrekannya dahulu, Rasulullah berkomentar, "mereka di dalam neraka." Salman mengisahkan kondisinya saat itu, "seakan, seluruh bumi terasa gelap bagiku" setelah Allah menrunkan ayat itu, Salman berujar, "perasaanku menjadi sangat ringan, seakan ada gunung yang disingkirkan dari atas tububku." ${ }^{4}$

Ibnu Jarir dan Ibnu Abi Hatim meriwayatkan dari As-Suddi, bahwa dia berkata, "ayat ini turun berkenaan dengan rekan-rekan Salman Al-Farisi". 35

Imam Ar-Razi menjelaskan secara rinci mengenai hal-hal dalam ayat di atas, menurut imam Ar-Razi terdapat makna yang beraneka ragam dalam lafadz (alladzina amanu) salah satunya adalah yang di maksud dengan orangorang yang beriman yakni mereka yang beriman sebelum Nabi Muhammad di angkat menjadi Rasul. Yang di maksud orang-orang itu antara lain Habib Al-najjar, Zayd bin Amr bin Nufayl, Waraqah bin Naufal, Salman al-Farisi dan seterusnya. Selain itu yang di maksud dengan lafadz alladzina amanu ialah mereka yang hanya beriman di lisan saja, bukan di hati (orang-orang munafiq)

33 Imam Suyuthi, Asbaabun Nuzul. Solo; Insan kamil. 2016 cet. I. Hal. 18

${ }^{34}$ Ibid, hal 18-19

${ }^{35}$ Ibid, hal 18-19 
serta orang-orang yang beriman kepada Nabi Muhammad SAW. ${ }^{36}$

Adapun yang dimaksud dengan lafadz (walladzina hadu) menurut Imam Ar-Razi terdapat beberapa pendapat, ada yang mengatakan maksud dari lafadz tersebut yaitu mereka yan bertaubat setelah mereka menyembah sapi, di samping makna tersebut ada yang mengatakan bahwa yang di maksud dari lafadz tersebut iyalah mereeka yang menisbatkan kelompoknya kepada yahuzda (anak tertua nabi yáqub) akan tetapi ada makna lain yang mengatakan bahwa makna dari lafadz tersebut adalah mereka yang ketika membaca kitab taurot sambil menggerak-gerakkan badannya. ${ }^{37}$

Selanjutnya imam Ar-razi juga mempunyai banyak pendapat mengenai makna dar lafadz wa an-nashara antara lain, ayat ini bermaksud menelaskan mengenai tempat yang ditempati oleh nabi Isa. Esa ini dinamai dengan desa nashirah. Ha lini di perkuat oleh Ibnu Abbas, Ibnu Jarih dan Qatadah, annashard ini juga bisa dimaknai dengan saling menolong atau bahu membahu dan hal ini dilakukan oleh mereka. dalam pendapat lain, dengan para pngikut Nabi Isa Al-Masih. ${ }^{38}$

\section{E. KONTEKS KE-INDONESIAAN}

Jika konsep toleransi bekaitan dengan agama, maka yang dimaksud toleransi di situ ialah membiarkan orang lain (agama lain) beraktivitas apa saja yang sesuai dengan ajaannya. Sehingga dari situ akan timbul sebuah kerukunan dalam masyarakat yang berbeda agama. Akan tetapi jika jika sikap toleran hanya terbatas pada diri pribadi, dalam arti tidak berhubungan dengan daerah lingkungan dan tidak mau ikut serta dalam membantu mengurusi kehidupan orang lain yang berbeda ras atau agama maka sikap toleran seperti itu hanya dikategorikan toleransi pasif. Konsep kerukunan yang seperti itu sangat jelas tidak sesuai dengan kenyataan dan keberadan masyarakat di Indonesia. Karena pada dasarnya, Indonesia sendiri sudah memiliki asas-asas toleransi yang tertera dalam pancasila dan Undang-Undang Dasar 1945. Maka dari itu, diperlukan kerukunan yang bersifat aktif yang dapat mengisolasi seluruh masyarakat di Indonesia. ${ }^{39}$

\footnotetext{
${ }^{36}$ Imam Ar-Razi, Tafsir al-Kabir, jilid III, hlm. 113

${ }^{37} \mathrm{Ibid}, \mathrm{hlm}, 303$

${ }^{38} \mathrm{Ibid}$, hal 113

${ }^{39}$ Ahsanul Khalikin \& Fathuuri. 2016. Toleransi Beragama di Daerah Rawan Konflik. Jakarta, Puslitbang Kehidupan Keagamaan. Hal. vii
} 
Secara otoritas, kerukunan terbagi menjadi dua jenis, yang pertama kerukunan eksklusif yaitu kerukunan yang bersifat absolut meyakini ajaran agama yang dianutnya. Sedangkan kerukunan inklusif ialah menghargai, menghormati, dan mendukung orang lain sesuai dengan apa yang diyakinkannya. Karena peluang untuk menjadi orang baik itu berdasarkan atas apa yang ditanam dalam hatinya. ${ }^{40}$

Salah satu tujuan pembangunan di bidang agama ialah kerukunan hidup beragama itu sendiri. Gagasan tersebut muncul dilatarbelakangi oleh kejadiankejadian yang menampakkan gejala meruncingkan hubungan antar agama. Gejala-gejala tersebut sering kali muncul pada pertengahan tahun enam puluhan. Yang mana pada masa itu terjadi pergejolakan gagasan agama yang dilontarkan oleh Prof. Mukti Ali, yang bertujuan untuk mempertemukan tokoh-tokoh dari berbagai agama lain. Alhasil, tersampailah berbagai gagasan dari berbagai agama dan sejak itu pula kegiatan dialog dalam menyampaikan gagasan keagamaan menjadi kegiatan utama dalam rangka membangun kerukunan hidap beragama. ${ }^{41}$

Berkembangnya berbagai agama menambah corak kemajemukan bangsa Indonesia. Meski demikian, kemajemukan di situ mengandung potensi pertentangan, namun sejarah mengatakan bahwa Indonesia adalah negara yang tidak pernah mengalami perang antar umat beragama. Karena mayoritas penduduk Indonesia menanamkan sikap toleran semenjak mereka lahir di daerah masingmasing. Hal ini menunjukkan bahwa setiap agama maupun budaya di Indonesia sudah memperkenalkan konsep toleran terhadap anak didiknya meski perlu di garis bawahi, bahwa perspektif toleransi dari berbagia kalangan itu berbeda-beda.

Bangsa ini telah menjamin kebebasan bagi untuk menganut agama apa saja yang dikehendakinya. Hal tersebut tertera dalam Undang-Undang Dasar 1945 pasal 28E ayat 1 dan 2,2 pasal 29 ayat 2, dan perumusan Deklarasi

\footnotetext{
${ }^{40} \mathrm{Ibid}$, hal vii-viii

${ }^{41}$ Alpizar, Islam, Toleransi, dan Kebebasan beragama. TOLERANSI: Media Komunikasi Umat Bergama,Vol.7, No.2 Juli-Desember 2015

${ }^{42}$ UUD 1945 pasal 28E ayat 1 berbunyi: "setiap orang bebas memeluk agama, dan beribadat menurut agamanya, memilih pendidikan dan pengajaran, memilih kewarganegaraan, memilih tempat tinggal di wilayah negara dan meninggalkan serta berhak kembali." Ayat ke 2, "setiap orang berhak atas kebebasan meyakini kepercayaan, menyatakan pikiran dan sikap, sesuai dengan hati nuraninya." Pasal 29 ayat 2, "negara menjamin kemerdekaan tiap-tiap penduduk untuk memeluk agamanya masing-masing dan untuk beribadah menurut agamanya dan kepercayaan." Lihat Abd. Moqsith Ghazali, Argumen Pluralisme Agama, hal. 229
} 
Universal Hak Asasi Manusia (DUHAM) Perserikatan Bangsa-Bangsa (PBB) tahun 1940 pasal $18 .^{43}$

Beberapa ayat al-Qur'an dan Hadits Nabi diperuntukkan umat Islam bahwa keluar dari Islam sangat tidak diridhai Allah dan Rasulnya. Dan barang siap yang murtad maka ia layak untuk dihukum mati sebagaimana yang dikatakan oleh Nabi "siapa saja yang pindah agama, maka bunublab". Dan di dalam al-Qur'an tidak ditemukan satu ayatpun untuk mengganti hukuman tersebut. ${ }^{44}$ Sebagaimana yang dikemukakan oleh pemikir Islam bahwa seseorang bebas untuk memeluk suatu agama, maka seharusnya dia juga bebas untuk berpindah agama. ${ }^{45}$

Kemudian, mengenai konsep toleran perspektif tafsir Ar-Razi jika diterapkan di Indonesia menurut penulis sangat akurat. Kerena tidak ada hal yang bertentangan antara pemikiran Imam Ar-Razi dengan landasan berfikir bangsa Indonesia, bahkan apa yang tertera dalam tafsirnya mengenai ayat toleransi umat beragama bisa dijadikan rujukan dan tolak ukur bagi kerukunan umat di Indonesia. Misalnya, seperti dalam pembahasan teologi, beliau mengemukakan bahwa tuhan adalah sumber kebenaran. Jika pernyataan ini diterapkan dalam bangsa Indonesia kemungkinan besar tidak akan timbul pertentangan dan tentunya berdampak baik, karena masing-masing agama di Indonesia pastinya sangat yakin terhadap tuhannya. Dan dari masing-masing agama tidak ada ajaran untuk menjatuhkan agama lain, dan negara inipun juga melarang hal tersebut. Dalam Islam sudah jelas untuk mempercayai tuhannya sendiri dan tidak perlu mengurusi tuhan agama lain, begitu pula dengan agama lainnya.

\section{F. KESIMPULAN}

Toleransi merupakan salah satu pengikat krukunan umat beragama. Dalam Islam sendiri toleransi dijadikan pijakan untuk menghargai dan menghormati agama lain dan tidak ada unsur pemaksaan terhadap agama lain untuk

43 "semua orang mempunyai hak atas kebebasan berpikir, berpendapat dan beragama; hak ini mengandung kebebasan mengganti agama atau keyakinan begitu juga menjalankan agama atau keyakinannya, sendiri atau bersama, baik di tempat umum maupun di rumah sendiri, baik ajaran, praktik, pemujaan dan pelaksanaan ibadah. Lihat, Ayang Utriza Yakin, Islam Moderat dan Isu-isu Kontemporer: demokrasi, pluralisme, kebebasan beragama non-Muslim, Poligami, dan Jihad. (jakarta: kencana, 2016), hal. 106

${ }^{44}$ Abd. Moqsith Ghazali, Argumen Pluralisme Agama, hal. 231

${ }^{45}$ Abd. Moqsith, "Tafsir Atas Hukum Murtad Dalam Islam." Ahkam 13, no. 2 (Juli 2013). http://journal.uinjkt.ac.id/index.php/ahkam/article/view/940 
beralih agama ke dalam agama Islam. Karena Islam sendiri mempunyai asas hidup kemajemukan dan memblehkan umatnya untuk hidup berdampingan dan menjalin hubungan dengan agama lain bahkan Islam sendiri menganjurkan hal tersebut sebagai mana yang pernah dilakukan oleh Nabi. Dengan demikian jika ada hal-hal yang kemungkinan akan bertentangan akan dapat diselesaikan baik dan bijak.

Banyak sekali ayat-ayat al-Qur'an yang dapat dijadikan sebagai pedoman untuk menumbuhkan rasa kesadaran dan menumbuhkan sifat toleran bagi seluruh penduduk bumi. Akan tetapi, perlu digaris bawahi bahwa sikap toleran dalam Islam seperti halnya rel kereta, sama-sama searah namun tidak untuk bersatu, dalam artian Islam melarang umatnya untuk mencampur adukkan ajarannya dengan ajaran agama lain.

Dalam kitabnya Ar-Razi mengemukakan beberapa pendapatnya di antaranya: pertama, Tuhan benar dan sumbe dari segala kebenaran.kedua, Imam Ar-Razi menyampaikan bahwa kekuasaan dan kebebasan tidak hanya bagi mereka yang kaya saja, namun bagi setiap oang fakir miskin juga berhak untuk mendapat kebebasan yang setara dan beliau sangat tidak setuju dengan pihak yang memandangan terhadap pihak lain dengan sebelah mata. 


\section{DAFTAR PUSTAKA}

Ahsanul Khalikin, Fathuri. Toleransi Beragama di Daerab Rawan Konflik. Jakarta: Puslitbang Kehidupan Keagamaan., 2016.

Al-Mukhdor, Yunus Ali. Toleransi Kaum Muslimin. Surabaya: PT. Bungkul Indah, 1994.

Alpizar. "Islam, Toleransi, dan Kebebasan beragama." TOLERANSI: Media Komunikasi Umat Bergama 7, no. 2 (Juli-Desember 2015).

Al-Suyuthi, Imam. Asbaabun Nuzul. Cet. I. Solo: Insan Kamil, 2016.

Ar-Razi. Mafaatihul Ghaib. Jilid. XXXI. Beirut: Libanon, Madir Azhar, 1997. At-Thabrani. sanadnya la' ba'sa bih. Al-Ausath. 751.

Bakar, 'Ala Abu. Islam yang Paling Toleran. Jakarta: Pustaka al Kautsar, 2005.

Dinata, Muhammad Ridha. "Konsep Toleransi Beragama Dalam Tafsir AlQur'an Tematik Karya Departemen Agama Republik Indonesia.” ESENSIA: Jurnal Ilmu-Ilmu Ushuluddin XIII, no. 1 (2012).

Effendy, Bachtiar. Masyarakat Agama Dan Pluralisme Keagamaan: Perbincangan Mengenai Islam, Masyarakat Madani dan Etos Kewirausahaan. Yogyakarta: Galang Press, 2001.

Ghazali, Abdul Moqshit. Argumen Pluralisme Agama: Membangun Toleransi Berbasis AL-Qur'an. Jakarta: Kata Kita, 2009.

Ghazali, Abdul Moqshit. “Tafsir Atas Hukum Murtad Dalam Islam.” Ahkam 13, no. 2 (Juli 2013).

Haris, Misbah Shoim. Spiritualitas Sosial Untuk Masyarakat Beradab. Jakarta: Penerbit Azura, 2003.

Hashim, Umar. Toleransi dan Kemerdekaan Beragama dalam Islam Sebagai Dasar Menuju Dialog Dan Kerukunan Antar Agama. Surabaya: PT. Bina Ilmu, 1997.

Lubis, Ridwan. Toleransi Beragama di Daerah Rawan Konflik. Jakarta: Puslitbang Kehidupan Keagamaan, 2016.

M. Thoriqul Huda, Eka Rizki Amelia, Hendri Utami. "Ayat-Ayat Toleransi Dalam Al-Qur'an Perspektif Tafsir Al-Misbah Dan Tafsir AL-Azhar.” Tribakti 30, no. 2 (Juli 2019).

Misrawi, Zuhairi. Al-Qur'an Kitab Toleransi, Tafsi Tematik Rahmatan Lil Alamin. Jakarta: Pustaka Oasis, 2010. 